\title{
KESESUAIAN PASAL 108 KHI TENTANG WASIAT PERWALIAN ANAK KEPADA BADAN HUKUM DENGAN HUKUM ISLAM
}

\author{
Mochammad Charitsal Chubba \\ Jl. Dapuan Bendungan Gg 5/No 14 Krembangan Utara Surabaya. \\ Email: Chubba147@Gmail.Com
}

\begin{abstract}
This is a bibliographical research that analyzes the appropriateness of article 108 of KHI (Islamic Law Compilation) concerning child trusteeship testament to legal entities with testamentary theories in Islamic law. In term of its formulation, it is known that article 108 of KHI does not have a basis and it contradicts the rules of Islamic law that exist according to the Shafi'i school of thought. In this case, there are two elements that are not in accordance with the rules of will in Islamic law, namely legal entities as recipient of will and guardianship as inherited object. It is because the legal entities are not individual recipient but an association consisting of several people who are not associated to religion and culture. In addition, the article is only based on a number of articles contained in the Civil Code and other laws, without detailed explanations regarding the articles and procedures that must be carried out and across the norms in the community. The solution that can be taken is the need for regulations regarding the criteria of legal entities that are permitted to accept the will and their responsibilities. And there should be a change from the word trusteeship to a representative that has a limited role compared to guardianship.
\end{abstract}

Keywords: KHI, will, trusteeship, legal entity, Islamic law

Abstrak: Artikel ini merupakan hasil penelitian pustaka yang menganalisis kesesuaian pasal $108 \mathrm{KHI}$ tentang wasiat perwalian anak kepada badan hukum dengan teori wasiat dalam hukum Islam. Dari segi perumusannya, diketahui bahwa pasal $108 \mathrm{KHI}$ tidak memiliki landasan nash dan bertolakbelakang dengan aturan hukum Islam yang ada menurut fikih madzhab Syafi'i. Dalam hal ini, terdapat dua unsur yang tidak sesuai dengan aturan wasiat dalam hukum Islam, yaitu badan hukum sebagai penerima wasiat dan perwalian sebagai benda yang diwasiatkan karena badan hukum bukanlah penerima perorangan melainkan sebuah perkumpulan yang terdiri dari beberapa orang yang tidak terikat agama serta budanya dan perwalian bukanlah sebuah barang melainkan jasa. Selain itu, pasal tersebut juga hanya berdasar pada sebagian pasal yang ada dalam KUHPerdata dan Undang-undang yang lain, tanpa penjelasan rinci terkait pasal dan prosedur yang harus dilakukan serta bersebrangan dengan norma yang ada di masyarakat. Adapun solusi yang dapat diambil adalah perlu adanya regulasi mengenai kriteria badan hukum yang diperbolehkan menerima wasiat serta tanggung jawabnya dan adanya perubahan dari kata perwalian menjadi perwakilan yang memiliki peranan terbatas disbanding perwalian. perubahan dari perwalian

AL-HUKAMA

The Indonesian Journal of Islamic Family Law

Volume 08, Nomor 02, Desember 2018; ISSN:2089-7480 
menjadi perwakilan sebab dalam perwakilan memiliki peranan yang terbatas dibandingkan dengan perwalian.

Kata Kunci: KHI, wasiat, perwalian, badan hukum, hukum Islam

\section{Pendahuluan}

Sebelum meninggal, orang yang mempunyai harta berwenang untuk mewasiatkan sebagian hartanya dengan batasan tidak melebihi $1 / 3$ dari hartanya kepada lembaga atau perorangan yang dianggap perlu bagi si mayit dan pelaksanaannya ketika si pewasiat sudah meninggal. Sebagaimana ulama Hanafiyah mendefinisikan wasiat sebagai pemberian hak memiliki sesuatu secara sukarela (tabarru) yang pelaksanaannya ditangguhkan, baik sesuatu tersebut berupa barang maupun manfaat. 1

Muhammad Jawaz Mughniyah mengemukakan bahwa rukun dan syarat sahnya suatu wasiat harus disandarkan kepada empat hal, yaitu orang yang berwasiat (musi), orang yang menerima wasiat (musa lab), barang yang diwasiatkan (musa bih) dan redaksi wasiat (sighat).2 Adapun syarat orang yang diserahi untuk menjalankan wasiat ada enam, yaitu: 1. beragama Islam; 2. balig; 3. berakal; 4. merdeka; 5. amanah; 6. cakap untuk menjalankan sebagaimana yang dikehendaki oleh yang berwasiat. 3

Sesuatu pembaharuan tampak dalam pasal $108 \mathrm{KHI}$, yang menjelaskan bahwa "Orang tua dapat mewasiatkan kepada seseorang atau badan hukum untuk melakukan perwalian atas diri dan kekayaan anak atau anak-anaknya sesudah ia meninggal dunia". Dalam pasal tersebut menyebutkan bahwa perbuatan orang tua yang melakukan wasiat perwalian anak kepada badan hukum sepeninggalnya adalah perbuatan yang sah untuk dilakukan. Tidak ditemukan penjelasan apapun dalam pasal $108 \mathrm{KHI}$, baik dari unsur terbentuknya pasal maupun akibat hukumnya, sehingga pada pasal tersebut memungkinkan terjadinya berbagai macam legal opini yang ditimbulkan dari frase pasal tersebut. Lahirnya pasal 108 tersebut tidak terlepas dari perumusan dan perencaan yang dilakukan oleh

1 Fatchur Rahman, Ilmu Waris, (Bandung: PT. Alma'arif Bandung, 1975), 50.

2 Abdul Manan, Aneka Masalab Hukum Perdata Islam di Indonesia, Jakarta: Kencana, 2006), 156.

3 Sulaiman Rasjid, Fiqh Islam, (Bandung: Sinar Baru Algensindo, 2008), 373 
para ulama dengan merujuk pada kitab-kitab fikih para ulama terdahulu serta penyesuaian dengan kondisi budaya, adat, dan kebiasaan masyarakat Indonesia. Berangkat dari permasalahan tersebut, maka menarik untuk melakukan pembahasan mengenai kesesuaian pasal $108 \mathrm{KHI}$ tentang wasiat perwalian anak kepada badan hukum dengan hukum Islam dalam artikel ini.

\section{Konsep Wasiat dalam Hukum Islam}

Esensi dalam berwasiat ada dua, yakni akad dan nilai manfaat. Ulama figh memberi contoh, harta karena bisa digunakan sebelum mati namun juga berbekas amal sholih atau fasid setelah mati. Adapun syarat sahnya wasiat ada dua, yaitu langsung/jelas dan mempunyai batasan waktu, sebagaimana contoh, aku berwasiat atas barang ini. (langsung/ elas). Aku berwasiat kepadamu setelah aku mati nanti (berjangka waktu).4

Secara bahasa wasiat artinya berpesan. Kata wasiat disebut dalam al-Qur'an sebanyak 9 kali. Dalam bentuk kata kerja, wasiat disebut 14 kali, dan dalam bentuk kata benda jadian disebut 2 kali. Seluruhnya disebut dalam al-Qur'an sebanyak 25 kali. Dalam penggunaannya, kata wasiat berarti berpesan, menetapkan, memerintahkan (QS. Al-'An'am: 151, 152, 153, al-Nisa': 131), mewajibkan (QS. al-'Ankabut: 8, Luqman: 14, al-Syura: 13, al-Ahqaf: 15), dan mensyariatkan (al-Nisa':11). Adapun suatu wasiat datang dari Allah, berarti suatu perintah sebagai suatu kewajiban yang harus dipatuhi pelaksanaannya.5

Wasiat dalam terminologi hukum perdata positif, sering disebut dengan istilah testament. Namun demikian, ada perbedaanperbedaan prinsipil antara wasiat menurut hukum Islam dan testament, terutama yang menyangkut kriteria dan persyaratan.6 Pendapat lain dari pengertian wasiat adalah pesan seseorang kepada orang lain untuk mengurusi hartanya sesuai dengan pesan sepeninggalnya. Jadi, wasiat merupakan tasarruf terhadap harta

4 Wahbah Zuhaily, Al-Fiqh al-Islam wa Adillatuhu, juz 8 (Damaskus: Dar al-Fikr, 2008), 17.

5 Ahmad Rofiq, Hukum Islam di Indonesia, (Jakarta: PT. Raja Grafindo Persada, 1997), 438.

6 Ibid., 439. 
peninggalan yang akan dilaksanakan setelah meninggalnya orang yang berwasiat, dan berlaku setelah orang yang berwasiat itu meninggal. Menurut asal hukumnya, wasiat adalah suatu perbuatan yang dilakukan dengan sukarela dalam segala keadaan. Oleh karena itu, dalam syariat Islam, tidak ada suatu wasiat yang wajib dilakukan dengan jalan putusan.7

Chairuman Pasaribu dan Suhrawardi K. Lubis, mengemukakan pengertian wasiat adalah "pemberian seseorang kepada orang lain, baik berupa barang, piutang ataupun manfaat untuk dimiliki oleh orang yang diberi wasiat setelah orang yang berwasiat mati."s Menurut T. M. Hasby ash Shiddieqiy, wasiat adalah suatu tasarruf terhadap harta peninggalan yang akan dilaksanakan sesudah meninggalnya orang yang berwasiat.9

Wasiat disyariatkan melalui al-Qur'an, Sunnah, dan ijma' dengan penjelasan sebagai berikut:

1. Al-Qur'an,10 dalam surat al-Baqarah ayat 180 dan 240 yang menunjukkan secara jelas mengenai hukum wasiat dan teknis pelaksanaannya, serta materi yang menjadi objek wasiat.

2. Sunnah,11 yang artinya:

"Wahai Rasulullah, aku mau berwasiat untuk menyerahkan seluruh hartaku". Beliau bersabda: "Jangan". Aku katakan: "Setengahnya" Beliau bersabda: "Jangan". Aku katakan lagi: "Sepertiganya". Beliau bersabda: "Ya, sepertiganya dan sepertiga itu sudah banyak. Sesungguhnya jika kamu meninggalkan ahli warismu dalam keadaan kaya itu lebih baik daripada kamu meninggalkan mereka dalam keadaan miskin lalu mengemis kepada manusia dengan menengadahkan tangan mereka (HR. Bukhari)

7 Dian Khairul Umam, Fiqih Mawaris Untuk IAIN, STAIS, PTAIS, (Bandung: Pustaka Setia, 1999), 237.

8 Suhrawardi K. Lubis, Hukum Waris Islam (Lengkap \& Praktis), (Jakarta: Sinar Grafika, 1995), 41.

9 T. M. Hasby Ash Shiddieqiy, Fiqh Mawaris, (Semarang: Pustaka Rizki Putra, 1997), 300.

10 Ahmad Rofiq, Hukum Islam di Indonesia..., 440.

11 Ibid., 442. 
Dengan demikian dapat dipahami bahwa wasiat itu penting, selain sebagai pelaksanaan ibadah untuk investasi kehidupan akhirat, dan wasiat akan memberi manfaat bagi kepentingan orang lain atau masyarakat pada umumnya, meskipun realisasinya dibatasi maksimal ${ }^{1} / 3$ dari harta si pewasiat. Ini dimaksudkan agar hak-hak ahli waris tidak terkurangi, sehingga mengakibatkan kehidupan mereka terlantar.

3. Ijma'

Praktek pelaksanaan wasiat ini telah dilakukan oleh umat Islam sejak zaman Rasulullah sampai sekarang. Tindakan yang demikian tidak pernah diingkari oleh seorangpun. Ketiadaan ingkar seseorang itu menunjukkan adanya ijma atau kesepakatan umat Islam bahwa wasiat merupakan syariat Allah Swt. dan Rasul-Nya didasarkan atas nas al-Qur'an maupun hadis nabi yang menerangkan tentang keberadaan wasiat.12 Semua ulama sepakat hukumnya wasiat adalah boleh.13

Berwasiat berarti membuktikan rasa tenggang rasa dan peduli terhadap orang lain, serta bukti solidaritas antar umat manusia dalam mencari dan memperbanyak perbuatan-perbuatan yang baik. 14

Secara garis besar syarat-syarat wasiat mengikuti rukunrukunnya. Dalam hal ini, para ulama berbeda pendapat dalam memberi uraian tentang rukun dan syarat wasiat. Sayyid Sabiq misalnya, menyebutkan rukun wasiat hanya satu, yaitu penyerahan dari orang yang berwasiat.15 Muhammad Jawwad Mughniyah menerangkan bahwa rukun wasiat ada empat yaitu: redaksi wasiat (sighat), pemberi wasiat (musi), penerima wasiat (musa lab), dan barang yang diwasiatkan (musa bib).16

Adapun Ibn Rusyd dan al-Jaziry mengemukakan pendapat ulama secara muqaranah (komparatif) ada 4 rukun wasiat:

1. Musi (orang yang berwasiat)

2. Musa lab (orang yang menerima wasiat)

12 M. Ali Hasan, Hukum Warisan Dalam Islam, (Jakarta: Bulan Bintang, 1996), 21.

13 Wahbah Zuhaily, Al-Fiqh al-Islam wa Adillatubu..., 19.

14 Ibid.

15 Ahmad Rofiq, Hukum Islam di Indonesia..., 449.

16 Muhammad Jawwad Mughniyah, Fiqh Lima Madzhab, (Jakarta: Lentera Basritama, 1996), 504. 
3. Musa bih (harta yang diwasiatkan)

4. Sighat (lafad ijab dan kabul)17

Adapun mengenai syarat masing-masing rukun wasiat tersebut adalah sebagai berikut:

1. Orang yang berwasiat

Disyaratkan orang yang memberi wasiat adalah orang yang ahli kebajikan, yaitu orang yang mempunyai kompetensi (kecakapan) yang sah. Keabsahan kompetensi didasarkan pada akal, kedewasaan, kemerdekaan, ikhtiyar, dan tidak dibatasi karena kedunguan atau kelalaian. Apabila pemberi wasiat orang yang kurang kompetensinya, yaitu karena masih anak-anak, gila, hamba sahaya, dipaksa, atau dibatasi, maka wasiatnya tidak sah.18

Seseorang yang hendak mewasiatkan haruslah sudah dewasa, akil, baligh, dan merdeka. Islam/kafir dan lakilaki/perempuan tidak merupakan syarat orang yang mewasiatkan.19 Sudarsono menerangkan syarat sahnya orang yang berwasiat ialah harus sudah akil baligh, mempunyai pikiran sehat, benar-benar berhak atas harta benda yang akan diwasiatkan. Di samping itu pewasiat tidak berada di bawah pengaruh yang tidak menguntungkan, seperti: tertipu, terpaksa, dan keadaan-keadaan lain yang sejenis.20

Pemberi wasiat dsyaratkan orang dewasa yang cakap melakukan perbuatan hukum, merdeka dalam pengertian bebas memilih dan tidak mendapat paksaan. Oleh karena itu, orang yang dipaksa dan orang yang tidak sehat pikirannya tidak sah wasiatnya. Namun, bila wasiat anak-anak yang sudah cakap melakukan perbuatan hukum, di kalangan ulama terjadi perbedaan pendapat. Imam Malik memandang sah kalau anakanak sudah mumayyir, tetapi Abu Hanifah tidak membenarkan

17 Ahmad Rofiq, Hukum Islam di Indonesia..., 449.

18 Sayyid Sabiq, Fikih Sunnah Jilid 14, cet.2, (Bandung: Al Ma'arif, 1988), 225.

19 Wahbah Zuhaily, Al-Figh al-Islam wa Adillatubu..., 48-50.

20 Sudarsono, Hukum Waris dan Sistem Bilateral, (Jakarta: PT. Melton Putra, 1991), 107. 
wasiat anak-anak, baik yang belum mumayyiz, maupun yang sudah mumayyiz:21

Pendapat lain dari Dian Khairul Umam dalam bukunya Fiqih Mawaris untuk IAIN, STAIN, PTAIS menerangkan bahwa musi adalah orang yang memberi wasiat kepada orang lain untuk menguruskan harta sesudah ia meninggal. Untuk sahnya wasiat, pemberi wasiat harus memenuhi syarat sebagai berikut: a) balig; b) berakal sehat; c) dengan sukarela atas kemauan sendiriz2

Para ulama sepakat bahwa orang yang berwasiat adalah setiap orang yang memiliki barang manfaat secara sah dan tidak ada paksaan. Namun, mereka berbeda dalam menentukan batas usia, karena ini erat kaitannya dengan kepemilikan. Imam Malik mengatakan wasiat orang safih (bodoh) dan anak-anak belum baligh hukumnya sah. Pendapat ini didasarkan pada riwayat Umar ibn al-Kattab yang membolehkan wasiat anak yang baru berumur 9 atau 10 tahun kepada seorang putri pamannya senilai 30 dirham.

Aturan bagi orang yang berwasiat juga diatur dalam pasal $194 \mathrm{KHI}$ yang berbunyi:

a. Orang yang telah berumur sekurang-kurangnya 21 tahun, berakal sehat dan tanpa adanya paksaan dapat mewasiatkan sebagian harta bendanya kepada orang lain atau lembaga.

b. Harta benda yang diwasiatkan harus merupakan hak dari pewasiat.

c. Pemilikan terhadap harta benda seperti dimaksud dalam pasal (1) ini baru dapat dilaksanakan sesudah pewasiat meninggal dunia.23

2. Orang yang menerima wasiat

Syarat orang yang menerima wasiat ialah harus ada orangnya ketika wasiat itu dibacakan, orangnya harus jelas, orangnya sudah bisa bertanggung jawab, merdeka lebih

21 Zainuddin Ali, Hukum Perdata Islam di Indonesia, (Jakarta: Sinar Grafika, 2009), 142.

22 Dian Khairul Umam, Fiqih Mawaris Untuk IAIN, STAIS, PTAIS..., 240.

23 Ahmad Rofiq, Hukum Islam di Indonesia..., 450. 
diutamakan.24 Para ulama sepakat bahwa orang-orang yang menerima wasiat adalah bukan ahli waris, dan secara hukum dapat dipandang sebagai cakap untuk memiliki suatu hak atau benda.25 Orang yang menerima wasiat harus ada pada saat wasiat tersebut dilakukan, atau penerima masih ada pada saat pemberi wasiat meninggal dunia. Adapun syarat yang kedua ini menjadi perdebatan di kalangan ulama apabila penerima wasait tersebut juga sebagai ahli waris; jadi penerima wasiat berkedudukan ganda.26

Musa lab adalah orang yang diberi wasiat untuk menguruskan harta pemberi wasiat sesudah ia meninggal. Musa lah harus memenuhi kriteria sebagai berikut:

a. Bukan termasuk ahli waris dan bukan orang yang sebelumnya memiliki harta yang akan diwasiatkan kepadanya.

b. Tidak meminta lebih selain ketentuan batas maksimal dalam menerima wasiat yaitu sepertiga, kecuali pewasiat menghendaki lain.

c. Orang yang menerima wasiat harus jelas dan tidak diragukan statusnya.

d. Orang yang menerima wasiat tidak dalam keadaan haji dan dapat diketahui keberadaannya dengan jelas.

e. Adanya iktikad baik antara penerima wasiat dan pemberi wasiat. 27

Selain kriteria di atas ada yang menambahkan syarat lain, yaitu:

a. Orangnya jelas, baik nama maupun alamatnya

b. Ia ada ketika pemberian wasiat

c. Cakap menjalankan tugas yang diberikan oleh pemberi wasiat. 28

3. Barang yang diwasiatkan

24 Wahbah Zuhaily, Al-Figh al-Islam wa Adillatubu..., 48-50.

25 Ahmad Rofiq, Hukum Islam di Indonesia..., 451.

26 Sudarsono, Hukum Waris dan Sistem Bilateral..., 108.

27 Muhammad bin Sholih, Syarh al-Mumta' 'Ala Zad al-Mustaqni', juz 5, (Beirut: alKitab al-'Alami Li al-Nasyri, 2005), 158-159.

28 Dian Khairul Umam, Fiqih Mawaris Untuk LAIN, STAIS, PTAIS..., 240. 
Ketentuan jumlah yang boleh diwasiatkan. Harta peninggalan hanya boleh diwasiatkan tidak lebih dari $1 / 3$. Perhitungan ini harus mengingat beberapa hal, yaitu: 1 . telah dikurangi utang-piutang mayit; 2 . telah dipotong biaya/belanja penguburan mayit; keseluruhan harta yang diwariskan itu ada pada saat pemberi wasiat (pewasiat) meninggal dunia.29 Adapun Wahbah Zuhaily mengemukakan bahwa syarat sesuatu yang bisa diwasiatkan ialah: a. harus berupa harta benda; b. tidak berubah bentuk; c. bisa dimiliki; d. spesifik dan tidak absurd; serta e. tidak digunakan dalam kemaksiatan.30

Disyaratkan agar yang diwasiatkan bisa dimiliki dengan salah satu cara pemilikan setelah pemberi wasiat mati. Dengan demikian, maka sahlah wasiat mengenai semua harta yang bernilai, baik berupa barang ataupun manfaat. Sah pula wasiat tentang buah dari tanaman dan apa yang ada di dalam perut sapi betina, sebab yang demikian dapat dimiliki melalui warisan. Oleh karena itu, selama yang diwasiatkan ada wujudnya di waktu yang mewasiatkan mati, orang yang diberi wasiat berhak atasnya. Ini jelas berbeda dengan wasiat mengenai barang yang tidak ada. Sah pula mewasiatkan piutang dan manfaat seperti tempat tinggal serta kesenangan. Tidak sah mewasiatkan yang bukan harta, seperti bangkai, dan yang tidak bernilai bagi orang yang mengadakan akad wasiat, seperti khamar bagi kaum muslimin.31

Harta atau barang yang diwasiatkan diisyaratkan sebagai harta yang dapat diserahterimakan hak pemilikiannya dari pemberi wasiat kepada penerima wasiat, sehingga tidak sah mewasiatkan harta atau barang yang belum jelas statusnya. Selain itu, harta yang diwasiatkan mempunyai nilai yang jelas atau bermanfaat bagi penerima wasiat bukan harta atau barang-barang yang diharamkan atau yang akan membawa kemudharatan bagi penerima wasiat. Namun, apabila harta yang diwasiatkan sifatnya samar-samar, termasuk ikan di empang dan semacamnya, masih dapat diwasiatkan.32

29 Sudarsono, Hukum Waris dan Sistem Bilateral..., 108.

30 Wahbah Zuhaily, Al-Fiqh al-Islam wa Adillatubu..., 48-50.

31 Sayyid Sabiq, Fikib Sunnah Jilid 14..., 229.

32 Zainuddin Ali, Hukum Perdata Islam di Indonesia..., 142. 
Dengan demikian, suatu harta yang diwasiatkan harus memenuhi syarat-syarat sebagai berikut:

a. Hartanya dapat diwariskan atau merupakan barang bernilai.

b. Sudah ada ketika wasiat itu dibuat.

c. Milik pemberi wasiat sendiri.33

4. Sighat wasiat

Sighat bermakna pernyataan yang jelas. Dalam hal ini pemberi wasiat menyatakan dengan jelas mengenai isi wasiatnya di hadapan dua orang saksi. Khusus mengenai pernyataan yang jelas tidak diharuskan secara tertulis, kecuali sebagai pemenuhan terhadap ketentuan hukum setempat.34

Sighat hendaklah menggunakan kata-kata yang tegas menyatakan maksud wasiat. Kata-kata yang menyatakan maksud wasiat, misalnya:

a. Saya berwasiat kepada saudara agar memberikan seperenam harta peninggalan saya untuk keperluan pembangunan masjid.

b. Saya percayakan kepada saudara agar memberikan seperempat dari harta peninggalan saya untuk kepentingan madrasah di desa saya. 35

Secara terpisah Imam Syafi'i berpendapat dalam buku 2 Fiqih Madzhab Syafi'i karya Ibnu Mas'ud bahwa syarat-syarat sahnya berwasiat ialah:

a. Yang berwasiat seorang mukallaf, merdeka serta melakukannya atas kemauan sendiri walaupun ia bodoh atau kafir. Tidaklah sah wasiat dari anak-anak, orang gila, dan orang yang terpaksa.

b. Tempat memberikan wasiat dihalalkan (dibolehkan) dalam agama Islam, seperti masjid, madrasah, dan lain-lainnya. Tidaklah sah berwasiat ke tempat-tempat yang diharamkan oleh agama, seperti gereja rumah berhala, tempat judi, dan lain-lainnya.

c. Tempat memberikan wasiat jelas ada dan ada pula ahli milik wasiat ketika berwasiat. Tidaklah sah wasiat orang Islam

33 Dian Khairul Umam, Fiqih Mawaris Untuk IAIN, STAIS, PTAIS..., 240.

34 Sudarsono, Hukum Waris dan Sistem Bilateral..., 108.

35 Dian Khairul Umam, Fiqih Mawaris Untuk IAIN, STAIS, PTAIS..., 240. 
kepada orang kafir, wasiat kepada jenazah, atau binatang ternak sebab semua itu tidak dapat memiliki wasiat tersebut.

d. Wasiat lebih dari sepertiga harta orang yang berwasiat. Bila ada seseorang berwasiat lebih dari sepertiga hartanya, yang sah hanyalah yang sepertiga itu, sedangkan selebihnya adalah hak waris. 36

Wasiat dapat dikatakan sah manakala melalui tiga tahapan, yaitu ungkapan, tertulis, atau petunjuk yang dapat memahamkan dan tidak menimbulkan kesalahpahaman. Imam Syafi,i menganggap sah wasiat yang dinyatakan dengan lisan tanpa harus dengan tulisan, karena lisan itu bisa dijadikan sumber hukum, sebagaimana kesaksian saksi di muka Pengadilan.37

Salah satu hadis dari Rasulullah saw. yang memuat pentingnya fungsi dari wasiat yang artinya adalah sebagai berikut:

"Sesungguhnya Allah telah bersedekah kepada kamu sekalian dengan sepertiga dari harta kamu sebagai penambah amal kebaikanmu. (HR. Daruqutni).

Menurut Sayyid Sabiq hadis tersebut adalah dhaif, namun boleh diamalkan karena berkenaan dengan sosial kemasyarakatan, selain itu manfaat dari wasiat adalah sebagai bukti manusia mendekatkan diri kepada Tuhannya yang telah menciptakannya dan juga mempererat tali silaturrahmi antara sesama kerabat penerima wasiat.38 Adapun hikmah lain dari pensyari'atan wasiat adalah sebagai berikut:

a. Sebagai tambahan amal baik yang terakhir dari seseorang yang akan meninggal.

b. Untuk menolong kepada kerabat dekat dalam rangka untuk kelangsungan hidupnya.

c. Untuk melindungi hak-hak waris, sehingga wasiat itu tidak melebihi sepertiga dari harta yang telah ditinggalkan oleh mushi terhadap harta peninggalannya.

36 Ibnu Mas'ud, Fiqih Madz̧hab Syafii (Edisi Lengkap) Buku 2, (Bandung: Pustaka Setia, 2007), 181.

37 Wahbah Zuhaily, Al-Figh al-Islam wa Adillatubu..., 48-50.

38 Ibid., 220. 
d. Terjadinya hubungan antar sesama ahli waris, sehingga tercipta kerukunan dan kasih sayang antara mereka semakin kuat.

\section{Badan Hukum Menurut Perundang-undangan}

Istilah badan hukum tidak ditemukan dalam KUHPerdata, yang ada adalah istilah "perkumpulan". Perkumpulan dipandang bukan sebagai badan pribadi melainkan sebagai perjanjian, maka pengaturannya terdapat dalam pasal 1653 sampai dengan pasal 1665 Bab Kesembilan tentang perjanjian Buku III khusus: "tentang perkumpulan". Pengaturan tersebut sebetulnya tidak tepat oleh karena badan hukum merupakan bagian badan pribadi, maka mestinya diatur dalam Buku I KUHPerdata.

Badan hukum adalah suatu badan yang dapat bertindak dalam hukum di samping manusia perorangan dan yang mempunyai hakhak, kewajiban-kewajiban, dan kepetingan-kepentingan hukum terhadap orang lain atau badan lain. Pendapat lain mengatakan, badan hukum yaitu kumpulan dari orang-orang yang bersama-sama mendirikan suatu badan (perhimpunan) dan kumpulan harta kekayaan yang ditersendirikan untuk tujuan tertentu (yayasan). Baik perhimpunan maupun yayasan kedua-duanya berstatus sebagai badan hukum, jadi merupakan person, pendukung hak dan kewajiban.

Dari beberapa pendapat tersebut dapat diketahui bahwa badan hukum sebagai subjek hukum berarti dapat melakukan perbuatan hukum untuk mencapai tujuan yang digariskan. Untuk itu, maka perbuatan hukum dilakukan oleh pengurus (organ badan hukum). Apabila perbuatan orang tersebut ternyata menimbulkan kerugian pada pihak lawan, sedangkan orang tersebut berbuat sesuai dengan garis kewenangan yang diberikan kepadanya, maka badan hukum dapat dipertanggungjawabkan (digugat). Sebaliknya badan hukum juga dapat menggugat pihak lawannya.

Istilah badan hukum merupakan terjemahan dari rechtspersoon (Belanda) atau persona moralis (Latin), legal persons (Inggris), atau zedelijk lichaam (Belanda). Badan hukum sebagai istilah dalam hukum dan kepustakaan kiranya sudah tidak asing lagi, namun ada juga yang 
menyebutnya dengan purasa hukum, awak hukum, pribadi hukum, dan sebagainya. 39

1. Syarat formal dan material Badan Hukum.

Suatu badan, perkumpulan atau badan usaha dapat berstatus sebagai badan hukum jika telah memenuhi syaratsyarat. Menurut doktrin syarat-syarat tersebut adalah:

a. Adanya kekayaan yang terpisah.

b. Mempunyai tujuan tertentu.

c. Mempunyai kepentingan.

d. Ada organisasi yang teratur.

Status badan hukum bagi suatu badan, badan usaha, perkumpulan merupakan suatu yang harus diperjuangkan, bukan sesuatu yang kodrati (alami/melekat dengan sendirinya). Kewenangan untuk memberikan status badan hukum terdapat pada menteri kehakiman dan untuk mendapat status itu, maka para pihak harus mengajukan permohonan kepada menteri kehakiman melalui ketua pengadilan negeri.

Syarat-syarat sebagaimana disebut oleh doktrin tersebut merupakan syarat material yang harus ada, sedangkan yang dimaksud dengan syarat formal ialah syarat-syarat yang harus dipenuhi sehubungan dengan permohonan untuk mendapatkan status sebagai badan hukum, misalnya yang diatur dalam pasal 36 KUHD, yang bunyi potongan pasalnya:

"Sebelum suatu perseroan terbatas bisa berdiri dengan sah, maka akta pendirianny atau naskah dari akta tersebut harus disampaikan terlebih dahulu kepada Menteri Kehakiman, untuk mendapat pengesahannya. Untuk tiap-tiap perubahan dalam syarat-syarat pendiriannya, dan dalam hal perpanjangan waktu, harus diperoleh pengesahan yang sama."

Pada akhirnya dalam penentuan status badan hukum atau bukan bagi suatu badan, badan usaha, perkumpulan tidaklah terlepas dari peranan hukum positif dari suatu negara.40

2. Kedudukan Badan Hukum.

39 Suhardana, et al., Hukum Perdata 1 Buku Panduan Mahasiswa, (Jakarta: PT. Gramedia Pustaka Utama, 1996), 57.

40 Ibid., 59. 
Untuk mengetahui kedudukan badan hukum, dapat secara jelas dilihat dalam Undang-undang. Selain itu dapat pula diketahui dari kebiasaan atau yurisprudensi. Pada beberapa badan atau perkumpulan (dalam arti luas) dengan tegas oleh Undangundang dinyatakan sebagai badan hukum, contoh: BRI dan BI adalah badan hukum. Terkadang Undang-undang tidak menyebutnya secara tegas, tetapi dengan peraturan sedemikian rupa, bahwa badan adalah badan hukum, contoh PTT dakan ordonasi 1931 terdapat peraturannya, tetapi tidak tegas dinyatakan PT'T sebagai badan hukum.

Pada badan, perkumpulan yang tidak dengan tegas dinyatakan sebagai badan hukum, penetapan kedudukan sebagai badan hukum dapat ditentukan dengan jalan melihat hukum yang mengaturnya dan jika dari peraturan diambil konklusi adanya sifat, ciri, atau dengan kata lain adanya unsur badan hukum, maka badan (perkumpulan) itu adalah suatu badan hukum.41

3. Macam-macam Badan Hukum.

Menurut ketentuan pasal 1653 KUHPerdata badan hukum dibedakan menjadi:

a. Badan hukum yang didirikan oleh pemerintah/kekuasaan umum, misalnya: propinsi, kota praja, dan bank pemerintah.

b. Badan hukum yang diakui oleh pemerintah/kekuasaan umum, misalnya: perseroan, gereja, dan organisasi-organisasi agama.

c. Badan hukum yang didirikan untuk maksud tertentu yang tidak bertentangan dengan Undang-undang dan kesusilaan, misalnya PT, perkumpulan asuransi, dan perkapalan.

Badan hukum dibedakan menjadi dua dengan memakai kriteria menurut sifatnya:

a. Badan hukum ketatanegaraan ialah badan yang dikuasai oleh peraturan-peraturan yang atas dasar tersebut badan tersebut didirikan/diakui, dan berhenti karena dihapuskan oleh penguasa yang berwenang, contohnya daerah otonom, propinsi, kabupaten, kota praja, lembaga-lembaga, majelis, dan bank-bank.

41 Ibid., 60. 
b. Badan hukum keperdataan ialah badan hukum yang didirikan atas dasar perjanjian-perjanjian yang dibuat sendiri, dan berhentinya diatur pula oleh perjanjian tersebut atau karena tujuannya telah tercapai, contohnya perhimpunan yang diatur dalam pasal 1653 dan seterusnya Buku III KUHPer, yayasan, badan hukum-badan hukum yang termasuk dalam hukum dagang firma yang berbadan hukum, koperasi, MAI, dan lainnya.

Pendapat-pendapat di atas tampak ada berbagai macam kriteria untuk menyebut/membedakan badan hukum dan tampak pula tidak ada kesepahaman dalam menentukan kriteriakriteria tersebut.42

4. Orang yang bertindak mewakili Badan Hukum.

Oleh karena badan hukum merupakan subjek hukum yang tidak berjiwa, maka sudah barang tentu untuk melakukan perbuatan-perbuatan hukum dibutuhkan bantuan, untuk itu harus diwakili oleh manusia, yang berbuat untuk dan atas nama badan hukumnya, dengan sebutan menjadi wakil dari badan hukum. Perwakilan yang dimaksud berdasarkan atas perjanjian, bukan atas dasar ditentukan Undang-undang, hal ini yang umum terjadi. Akan tetapi, jika diamati secara teliti tentang siapa yang ditunjuk mewakili badan hukum, hal ini biasanya terdapat dalam anggaran dasar dan anggaran rumah tangga dari badan hukum.

Pasal 1654 KUHPerdata menunjukkan bahwa badan hukum mempunyai kewenangan bertindak/berbuat, sedangkan dalam pasal 1655 KUHPerdata menunjukkan siapa yang dapat mewakili badan hukum untuk bertindak, yaitu pengurusnya (de bestuurders) atau direksinya dan sebutan lainnya yang sama dikenal dengan istilah "organ" badan hukum. Batas kewenangan berbuat dari organ tersebut diatur dalam Undang-undang, anggaran dasar, anggaran rumah tangga badan hukumnya. Jadi "organ" melalui pengurus, direksi, memiliki kewenangan bertindak atas nama (in naam) badan itu.

Adanya pembatasan atas kewenangan organ berarti bahwa organ badan hukum tersebut tidak dapat berbuat sewenang-

42 Ibid. 
wenang, tetapi dibatasi sedemikian rupa oleh ketentuan intern yang berlaku dalam adan hukum, baik yang termuat dalam anggaran dasar maupun peraturan-peraturan lain. 43

5. Tanggung jawab Badan Hukum.

Apabila organ badan hukum dalam melakukan perbuatannya ternyata melanggar atas kewenangannya, maka yang harus bertanggung jawab bukanlah badan hukumnya, tetapi pribadi organ tersebut, kecuali jika perbuatan tersebut menguntungkan badan hukum, atau organ yang lebih tinggi menyetujuinya. Jadi atas kerugian yang diderita pihak ketiga yang disebabkan oleh perbuatan organ badan hukum yang melanggar batas wewenangnya, tidak dapat dipertanggungjawabkan terhadap badan hukum, kecuali bermanfaat bagi badan hukum atau disetujuinya. Pasal 45 KUHD juga mengatur mengenai batas-batas wewenang dari organ badan hukum dalam melakukan perbuatan untuk badan hukum serta sanksi atas pelanggaran terhadap batas wewenang tersebut.44 Berikut bunyinya:

Tanggungjawab para pengurus adalah tak lebih daripada untuk menunaikan tugas yang diberikan kepada mereka dengan sebaik-baiknya; merekapun karena segala periktan dari perseroan, dengan diri sendiri tidak terikat kepada pihak ketiga. Sementara itu apabila merek melanggar sesuatu ketentuan dalam akta, atau tentang perubahan yang kemudian diadakannya mengenai syarat-syarat pendirian, maka, atas kerugian yang karenanya telah diderita oleh pihak ketiga, mereka itupun masing-masing dengan diri sendiri bertanggungjawab untuk seluruhnya.

\section{Kesesuaian Pasal 108 KHI Tentang Wasiat Perwalian Anak Kepada Badan Hukum dengan Hukum Islam}

Kompilasi Hukum Islam atau yang lebih dikenal KHI adalah salah satu dari produk hukum yang dirancang oleh para pakar hukum dan hukum Islam. KHI merupakan produk hukum berupa

43 Ibid., 61

44 Ibid., 62. 
Instruksi Presiden (Inpres) yang dibentuk pada tahun 1991 yang mana dalam tatanan hierarki hukum Indonesia Inpres berada setelah Peraturan Pemerintah (PP), yang berakibat hukum mengikat bagi warga negara yang beragama Islam dan menjadi salah satu rujukan dalam hukum Indonesia dan rujukan dalam proses beracara di lingkup Pengadilan Agama se-Indonesia.

Salah satu referensi Hakim Pengadilan Agama adalah Kompilasi Hukum Islam, di mana isinya adalah rangkuman dari beberapa pendapat ulama yang ada di kitab-kitab fikih. Agar mudah diterima di masyarakat, KHI tidak melepas adat yang berlaku begitu saja, sehingga beberapa adat yang berkembang dan tidak bertentangan dengan syariat tetap dijadikan pertimbangan hukum. KHI memuat beberapa peraturan di antaranya tentang perkawinan, kewarisan dan perwakafan.

Salah satu yang menarik dalam KHI dan menjadi objek kajian pada artikel ini terkait wasiat perwalian dari orang tua kepada badan hukum yang ada pada pasal 108 Bab Perwalian Buku I yang berbunyi "Orang tua dapat mewasiatkan kepada seseorang atau badan hukum untuk melakukan perwalian atas diri dan kekayaan anak atau anakanaknya sesudah ia meninggal dunia."

Pengertian secara umum pasal tersebut bermakna bahwa orang tua sebelum meninggal dunia dapat membuat pernyataan wasiat yang berisi tentang pelimpahan perwalian atas anak-anaknya kepada badan hukum. Namun, secara penulis tidak menemukan penjelasan dari pasal tersebut, baik dalam pengertian pasal maupun asal usul dari adanya pasal tersebut dan juga pasal ini tidak memiliki tindak lanjut, yang mana objek dari makna perwalian dan badan hukum belum dijelaskan secara mendetail.

Asal usul lahirnya pasal 108 tidak diketahui penjelasannya dalam KHI. Namun, jika dilihat dari perspektif yang berbeda, pasal tersebut membawa suatu solusi atau penyelesaian sebuah konflik yang mungkin saja dapat terjadi di era saat ini. Selanjutnya, keberadaan pasal tersebut terletak di antara dua pasal yang tidak memiliki keterkaitan hubungan antara pasal sebelumnya dengan pasal sesudahnya serta tidak adanya penjabaran dalam tiap-tiap unsur yang terdapat pada pasal tersebut sehingga dapat 
menimbulkan multitafsir yang beragam bagi orang yang memahaminya.

Adapun kedua pasal yang dimaksud berbunyi:

Perwalian hanya terhadap anak yang belum mencapai umur

21 tahun dan atau belum pernah melangsungkan perkawinan.

(2) Perwalian meliputi perwalian terhadap diri dan harta kekayaanya. (3) Bila wali tidak mampu berbuat atau lalai melaksanakan tugas perwaliannya, maka pengadilan Agama dapat menunjuk salah seorang kerabat untukbertindak sebagai wali atas permohonan kerabat tersebut. (4) Wali sedapat-dapatnya diambil dari keluarga anak tersebut atau oranglain yang sudah dewasa, berpiiran sehat, adil, jujur dan berkelakuan baik, atau badan hukum. (Pasal 107 KHI)

Pengadilan Agama dapat mencabut hak perwalian seseorang atau badan hukum dan menindahkannya kepada pihak lain atas permohonan kerabatbya bila wali tersebut pemabuk, penjudi, pemboros,gila dan atau melalaikan atau menyalah gunakan hak dan wewenangnya sebagai wali demi kepentingan orang yang berada di bawah perwaliannya. (Pasal $109 \mathrm{KHI})$

Tidak adanya penjelasan dari pasal tersebut serta penggunaan dan ketentuan dari wasiat yang digunakan pada bagian perwalian menimbulkan pertanyaan, hal tersebut bertentangan dengan ketentuan wasiat dalam hukum Islam yang ada atau justru sebaliknya sebagai alternatif dari ketentuan tentang wasiat yang telah ada. Aturan nas tentang ketentuan wasiat terdapat dalam qur'an surah Baqarah ayat 180 dan hadis yang diriwayatkan oleh Bukhori No. 2537.

Kedua nas tersebut dengan jelas menerangkan bahwa apabila telah dekat ajal seseorang hendaknya ia berwasiat kepada bapak-ibu dan kerabat karibnya dengan cara yang baik, dan jumlah dari harta yang hendak diwasiatkan tidak lebih dari sepertiga harta peninggalan si pewasiat. Nas tersebut menjelaskan aturan wasiat secara global tanpa mengkhususkan suatu penjelasan atau aturan tertentu, sedangkan aturan dalam pasal 108 menyebutkan penjelasan yang tidak termuat dan di luar aturan nas yang ada. Singkatnya dasar dari 
pasal 108 tidak terdapat dalam nas yang ada, baik dalam al-qur'an, alhadis maupun fikih Imam Syafi'i sehingga pasal tersebut dapat disebut sebagai pasal baru yang dihasilkan dari pemikiran para perumus KHI

Pasal 108 KHI dalam hukum Indonesia memiliki keterkaitan dengan aturan yang ada dalam KUHPerdata, bukan aturan mengenai wasiat namun aturan mengenai pemberian perwalian kepada badan hukum. Kedua aturan hukum tersebut memiliki perbedaan yang mencolok, dalam KUHPerdata, perwalian dapat dialihkan kepada badan hukum sedangkan dalam hukum Islam perwalian melekat pada orang tua kandung dan tidak dapat dialihkan kepada badan hukum. Untuk wasiat dalam hukum Islam hendaknya sesuatu benda yang dapat diambil kemanfaatannya dan terbatas pada benda, sedangkan dalam KUHPerdata wasiat dapat berupa apa saja yang dapat memberikan manfaat kepada penerima wasiat.

Lebih lanjut, dalam pencarian mengenai penerapan pasal tersebut di lingkup pengadilan ternyata belum ada kasus terkait penerapan pasal tersebut, disebabkan masih minimnya pengetahuan dari masyarakat akan pasal itu dan juga masih banyaknya masyarakat yang menggunakan adat dan kebiasaan dalam wasiat dan peralihan wali anak. Hal ini terpengaruh pada pemikiran dan kepercayaan masyarakat akan pemberian status wali kepada seseorang yang bukan bagian dari keluarga, sebab dalam masyarakat Indonesia masih memegang nilai-nilai kesopanan.

Peraturan terkait pasal tersebut banyak tercantum pada KUHPerdata, sedangkan dalam peraturan yang lain hanya menyebutkan bagian-bagian tertentu, seperti peraturan mengenai badan hukum terdapat pada KUHD dan Undang-undang Tentang Perseroan. Peraturan mengenai perwalian ada pada Undang-undang Perkawinan dan peraturan mengenai wasiat hanya terdapat di KUHPerdata, sedangkan peraturan yang menyebutkan secara keseluruhan tidak ada. Hal ini yang tentu mewajibkan penjelasan yang terperinci terkait aturan dan ketentuan dari wasiat perwalian kepada badan hukum, sehingga tidak menimbulkan pro-kontra dalam penjelasan pasal tersebut. Selain itu, juga tidak ditemukan prosedur dan tata cara mengenai proses dari pemberian wasiat perwalian kepada badan hukum. 
Pasal 108 KHI ini bagaikan pedang bermata dua, yang mana satu sisi memberikan sisi positif dan satu sisi memberikan sisi negatif. Sisi positif dari pasal 108 ialah sebagai solusi dari sebuah permasalahan yang mungkin terjadi mengenai perwalian anak dari orang tua yang meninggal untuk dialihkan perwaliannya kepada badan hukum, sedangkan sisi negatifnya ialah pasal tersebut bertolak belakang dengan ketentuan nas yang ada. Pasal tersebut juga tidak menjelaskan dan mendefinisikan dengan baik makna dan maksudnya.

Adapun jika dianalisis menggunakan ketentuan wasiat dalam hukum Islam dapat diketahui dari penjelasan berikut:

1. Orang tua sebagai pemberi wasiat (musi)

Beberapa ahli menerangkan syarat dari pemberi wasiat ialah harus akil, baligh, mempunyai pikiran sehat, benar-benar berhak atas harta benda yang akan diwasiatkan, tidak berada di bawah pengaruh yang tidak menguntungkan, seperti: tertipu, terpaksa, dan keadaan-keadaan lain yang sejenis, dengan arti harus dilakukan secara sukarela atas kemauan sendiri. Para ulama sepakat bahwa orang yang berwasiat adalah setiap orang yang memiliki barang manfaat secara sah dan tidak ada paksaan.

Orang tua sebagai pemberi wasiat dalam hal ini sudah memenuhi syarat dan rukun dari wasiat, yaitu balig, merdeka, atas kemauannya sendiri, tanpa paksaan, harta/benda yang diwasiatkan milik pribadi serta dalam harta/benda memiliki kemanfaatan terhadap barang tersebut. Orang tua dalam hal ini bertindak penuh sebagai al-musi, karena orang tua mempunyai hak atas benda yang akan diwasiatkan, yaitu perwalian atas anaknya kepada badan hukum. Akan tetapi, perlu diperhatikan bahwa orang tua yang berhak melakukan perbuatan tersebut ialah orang tua yang berstatus kandung atau orang tua yang melahirkan anak tersebut bukan orang tua yang berstatus angkat maupun adopsi, begitupun bagi orang tua tiri tidak berhak melakukan wasiat perwalian tanpa persetujuan dari orang tua kandungnya.

2. Badan hukum selaku penerima wasiat (musa lab)

Badan hukum dikategorikan sebagai penerima wasiat sebab dalam hukum perdata badan hukum termasuk sebagai subjek hukum yang disamakan dengan orang, sehingga badan 
hukum dapat melakukan perbuatan hukum berdasarkan pada peraturan yang mengikat dan berlaku atas badan hukum tersebut.

Adapun pendapat beberapa ahli mengenai penerima wasiat harus memenuhi syarat sebagai berikut: a. beragama Islam; b. balig; c. berakal; d. merdeka; e. amanah; f. cakap untuk menjalankan sebagaimana yang dikehendaki oleh yang berwasiat. Lebih lanjut penerima wasiat harus: a. Jelas orangnya, baik nama maupun alamatnya; b. ada ketika pemberian wasiat. Orang-orang yang menerima wasiat adalah bukan ahli waris, dan secara hukum dapat dipandang sebagai cakap untuk memiliki suatu hak atau benda.

Melihat konteks mengenai penerima wasiat, dapat diketahui bahwa badan hukum tidak termasuk kategori sebagai penerima wasiat, sebab dalam organ struktural yang ada pada badan hukum terdapat banyak susunan yang terbentuk, maka perlu adanya penentuan mengenai orang yang menerima amanah dan tanggung jawab untuk menjalankan tugas sebagai penerima wasiat. Penerima wasiat sebisa mungkin adalah orang yang seagama yaitu Islam, sebab jika lain agama yang menerima wasiat tersebut dikhawatirkan dapat menimbulkan konflik antara penerima dan pemberi wasiat.

Penunjukkan badan hukum sebagai penerima dari wasiat perlu adanya penetapan yang mendalam, seperti sifat dan jenis badan hukum yang dapat menerima sebuah wasiat perwalian, lalu kondisi dan keadaan dari badan hukum yang dapat menerima wasiat, dan perlu adanya kepercayaan dan kejujuruan dari badan hukum tersebut jika dipilih menjadi penerima wasiat. Hal-hal semacam itu yang perlu adanya perhatian, terlebih lagi pada saat ini peristiwa tersebut bisa saja terjadi namun tanpa melalui sebuah prosedur yang sesuai.

3. Perwalian atas diri anak diartikan sebagai benda yang diwasiatkan (musa bib)

Benda wasiat adalah suatu harta kekayaan yang dimiliki sepenuhnya dari pemberi wasiat untuk diberikan kepada penerima wasiat guna sebagai penerus dari pemberi sebelumnya. Benda wasiat dalam aturan hukum Islam ialah benda yang memiliki kemanfaatan atau harta kekayaan yang dapat dikelola 
dan diambil sebuah kemanfaatannya, namun dalam pasal ini benda wasiat digantikan dengan perwalian atas diri anak yang dijadikan sebagai objek wasiat.

Perwalian atas diri anak yang dijadikan sebagai objek/benda wasiat tersebut tidak layak, sebab perwalian merupakan suatu tindakan atau perbuatan bukan benda. Perwalian tidak bersifat statis namun mengikuti perkembangan dari hal yang diembannya. Jika anak yang diwalikan adalah anak tunggal yang mewarisi seluruh harta kekayaan dari orang tuannya, maka jumlah harta wasiat telah melebihi ketentuan yang ada, namun sebaliknya jika anak yang diwalikan memiliki banyak saudara dan tiap-tiap saudaranya mendapat bagian sesuai ketentuan, maka wali tersebut secara otomatis membiayai dari anak yang diwalikan kepadanya.

Pendapat beberapa ahli mengenai ketentuan harta benda yang diwasiatkan, yaitu:

a. Jumlah harta peninggalan yang boleh diwasiatkan tidak lebih dari $1 / 3$. Perhitungan ini harus memperhitungkan terlebih dahulu utang-piutang mayit dan biaya/belanja penguburan mayit.

b. Keseluruhan harta yang diwariskan itu ada pada saat pemberi wasiat (pewasiat) meninggal dunia.

c. Harta atau barang yang diwasiatkan adalah harta yang dapat diserahterimakan hak pemilikiannya dari pemberi wasiat kepada penerima wasiat.

d. Harta yang diwasiatkan mempunyai nilai yang jelas atau bermanfaat bagi penerima wasiat bukan harta atau barangbarang yang diharamkan atau yang akan membawa kemudharatan bagi penerima wasiat.

e. Milik pemberi wasiat sendiri.

Dalam hal perwalian bukan harta/benda yang dijadikan sebagai harta wasiat melainkan pribadi dari seorang anak yang diwasiatkan perwaliannya kepada lembaga/badan hukum memiliki berbagai ketimpangan, seperti batas usia anak yang diwalikan, perbuatan yang dapat diwalikan kepada badan hukum, kebutuhan pribadi si anak yang harus dipenuhi, dan pembiayaan 
yang dilakukan oleh badan hukum kepada si anak yang dalam perwaliannya.

Adanya wasiat perwalian anak kepada badan hukum memberikan celah kepada orang tua yang "tidak mempercayakan anaknya kepada saudara atau kerabatnya" untuk memperalihkan perwalian anaknya kepada lembaga yang berlabel hukum untuk menjadi wali bagi si anak setelah sepeninggal orang tuanya, namun di sisi lain dengan beralihnya tanggung jawab dari orang tua kepada badan hukum memberikan kekaburan akan jenis dari badan hukum yang dipilih serta tugas, tanggung jawab dan jaminan dari badan hukum setelah dilimpahkan wewenang perwalian kepada keluarga dari si anak yang diwalikannya.

4. Kata wasiat yang diartikan sebagai lafadz dari akad wasiat (sighat).

Menurut beberapa ahli bahwa sighat bermakna pernyataan yang jelas, dalam hal ini pemberi wasiat harus menyatakan dengan jelas mengenai isi wasiatnya di hadapan dua orang saksi. Lebih jelasnya, sighat adalah serah terima antara pemberi wasiat dengan penerima wasiat yang status pemilikannya berlaku sesudah pewasiat wafat dan diisyaratkan melalui lafaz yang jelas mengenai barang atau harta yang menjadi objek wasiat, baik secara tertulis maupun secara lisan yang kemudian disaksikan oleh dua orang saksi. Khusus mengenai pernyataan yang jelas tidak diharuskan secara tertulis, kecuali sebagai pemenuhan terhadap ketentuan hukum setempat. Sighat hendaklah menggunakan kata-kata yang tegas menyatakan maksud wasiat.

Kesesuaian antara penjelasan mengenai ketentuan sighat antara pemberi dan penerima wasiat dengan pengunaan kata wasiat dalam Pasal 108 sudah sesuai, sebab dalam pasal tersebut menyatakan dengan jelas perihal pernyataan yang dilakukan oleh pemberi kepada penerima wasiat. Dalam pasal itu juga terdapat penegasan dengan penggunaan kata wasiat di awal kalimat pasal tersebut.

Setelah melihat penjabaran dari kesesuaian antara rukun dan syarat dari wasiat dengan kata perkata pada pasal tersebut, terdapat dua hal yang tidak sesuai, yaitu pertama badan hukum sebagai penerima wasiat dan kedua perwalian diri anak sebagai benda yang diwasiatkan. Adapun, jika terdapat salah satu dari rukun dan syarat 
dari wasiat tidak terpenuhi, maka wasiat tersebut telah gugur dengan sendirinya, begitupun dengan perwalian dan badan hukum yang ada dalam pasal 108 tidak dapat berlaku.

Ketentuan wasiat dalam nas yang telah dipaparkan sebelumnya menerangkan tidak adanya penyebutan penerima wasiat secara khusus dan sebuah perwalian sebagai barang yang dapat diwasiatkan. Hal ini memperkuat bahwa pasal 108 tersebut tidak memiliki dasar pembentuk pasal, serta pasal tersebut bertentangan dengan ketentuan wasiat yang ada, yaitu pada bagian penerima wasiat dan objek barang yang diwasiatkan.

Dengan demikian, dapat dikatakan bahwa tidak adanya nas yang mendasari lahirnya pasal tersebut serta tidak adanya kesesuaian dengan ketentuan wasiat menggambarkan bahwa pasal tersebut dapat dikatakan terlahir dari pemikiran para ahli perumus KHI. Ketidaksesuaian konten pasal $108 \mathrm{KHI}$ dengan konsep wasiat dalam hukum Islam dan aturan yang terkait, menunjukkan bahwa pasal 108 KHI tidak seharusnya ada atau pasal tersebut tidak harus tercantum dalam KHI.

Ketidaksesuaian yang dimaksud adalah badan hukum sebagai penerima dan perwalian sebagai benda wasiat. Badan hukum dalam strukturnya memiliki organ kepengurusan yang mendirikan suatu badan hukum, pemberian tanggung jawab kepada badan hukum memberikan tanda tanya kepada siapa harusnya tanggung jawab tersebut diterima sedang dalam organ badan hukum terdiri lebih dari seorang. Penerimaan tanggung jawab yang menjadikan badan hukum tidak layak untuk dijadikan sebagai penerima wasiat disebabkan penunjukkan perwakilan dari badan hukum masihlah belum jelas.

Penunjukkan badan hukum sebagai penerima wasiat menimbulkan ketimpangan pada bentuk badan hukum. Di Indonesia badan hukum dapat berbentuk Perusahaan Terbatas (PT), Perseoran, Yayasan Amal, dan sebagainya. Bentuk badan hukum yang tidak tercantum dalam penjelasan pasal tersebut berdampak pada kurang tepatnya badan hukum yang ditunjuk menjadi penerima wasiat.

Selanjutnya perwalian yang dikategorikan sebagai benda wasiat, bukanlah benda yang dapat diwasiatkan melainkan tanggung 
jawab dari seseorang kepada orang lain untuk menjalankan sebuah amanah tertentu dan perwalian juga memiliki makna sifat dan makna kerja. Selain itu, perwalian dalam pasal tersebut juga tidak memiliki penjelasan yang rinci dan mendetail mengenai ruang lingkup dan hal-hal yang terkait dengan perwalian, seperti batas perwalian, tanggung jawab wali, gugurnya wali, dan sebagainya.

Perwalian dalam pasal $108 \mathrm{KHI}$ memiliki dua perspektif, yaitu perspektif hukum Islam dan perspektif hukum positif, yang mana dari kedua perspektif tersebut bertentangan satu sama lain. Perwalian perspektif hukum Islam menerangkan bahwa suatu perwalian tidak dapat beralih peran kepada badan hukum, kecuali wali yang ada dalam susunan perwalian dalam hukum Islam. wali dalam hukum Islam tidak hanya bertindak dalam pemeliharaan dan perawatan anak, saja melainkan bertindak menjadi wali dalam pernikahan. Perwalian dalam perspektif hukum positif memberikan kebebasan untuk diberikan kepada siapa pun selama orang yang menjadi wali sudah dewasa dan cakap dalam bertindak hukum. Hukum positif juga tidak membebankan pada satu pihak dan memberika keleluasaan dalam memberikan perwalian.

Perbedaan dalam perwalian itu memberikan perbedaan dalam penggunaannya, sama halnya dengan penggunaan kata perwalian dalam KHI dengan penggunaan kata perwakilan dalam UU Perkawinan. Penggunaan kata perwalian dan perwakilan dalam dua hukum tersebut berdampak pada kegunaan antar kata. Kata perwalian bermakna luas tidak hanya sebatas pemeliharaan, namun juga pernikahan dan mempunyai tanggung jawab yang lebih luas dari seorang wakil, sedangkan kata perwakilan bermakna bertindak atas perintah/amanah yang diberikan dari seseorang kepada orang lain untuk melakukan tugas tersebut dan hanya memiliki tanggung jawab kepada orang yang memberi perintah/amanat. Perbedaan makna perwalian dan perwakilan harus dijadikan dasar perubahan dari pasal $108 \mathrm{KHI}$, guna memperjelas fungsi dan peran dari perwalian kepada badan hukum.

Oleh karena itu, adanya pasal $108 \mathrm{KHI}$ yang tidak mempunyai landasan nas serta tidak memiliki kesesuaian dengan syarat dan rukun wasiat dapat dikatakan bahwa pasal tersebut gugur dan tidak layak untuk dijadikan salah satu bagian dari bab terkait tentang 
wasiat. Selain itu, perlu adanya perubahan dalam hal pemilihan kata yang dapat memberikan makna yang jelas dan konkrit, yaitu dari kata perwalian diganti menjadi perwakilan, serta perlu adanya regulasi guna memperjelas aturan mengenai pemberian perwalian kepada badan hukum.

\section{Penutup}

Ketetapan pasal $108 \mathrm{KHI}$ tentang wasiat perwalian anak kepada badan hukum tidak memberikan penjelasan dan definisi yang kongkrit mengenai maksud dan tujuannya, serta bertolak belakang dengan ketentuan nas dan aturan lain terkait wasiat. Berikutnya, peraturan negara mengenai wasiat perwalian kepada badan hukum hanya ada pada beberapa peraturan tertentu dan tidak ada peraturan yang menjelaskan mengenai prosedurnya. Selain itu, tersebut juga bersebrangan dengan nilai-nilai kesopanan yang ada di masyarakat.

Pasal 108 KHI tidak sesuai dengan aturan hukum Islam yang ada menurut fikih Madzhab Imam Syafi'i karena dalam pasal tersebut terdapat dua unsur yang tidak sesuai dengan aturan wasiat dalam hukum Islam, yaitu mengenai badan hukum sebagai penerima wasiat dan perwalian sebagai benda yang diwasiatkan, sebab perwalian bukanlah sebuah barang melainkan jasa dan badan hukum bukanlah penerima perorangan melainkan sebuah perkumpulan yang terdiri dari beberapa orang yang tidak terikat agama dan budaya.

Dengan demikian, perlu adanya perubahan redaksi pasal tersebut, yaitu dari perwalian menjadi perwakilan sebab perwakilan memiliki peranan yang terbatas dibandingkan dengan perwalian, dan perlu adanya regulasi mengenai kriteria badan hukum yang diperbolehkan menerima suatu wasiat atau tanggung jawab sejenisnya.

\section{Daftar Pustaka}

Abdul Manan. Aneka Masalah Hukum Perdata Islam di Indonesia, Jakarta: Kencana, 2006.

Ahmad Rofiq. Hukum Islam di Indonesia, Jakarta: PT. Raja Grafindo Persada, 1997. 
Dian Khairul Umam. Fiqih Mawaris Untuk LAIN, STAIS, PTAIS, Bandung: Pustaka Setia, 1999.

Fatchur Rahman. Ilmu Waris, Bandung: PT. Alma'arif Bandung, 1975.

Ibnu Mas'ud. Fiqih Madæ̧hab Syafi'i (Edisi Lengkap) Buku 2, Bandung: Pustaka Setia, 2007.

M. Ali Hasan. Hukum Warisan Dalam Islam, Jakarta: Bulan Bintang, 1996.

Muhammad bin Sholih. Syarh al-Mumta' 'Ala Zad al-Mustaqni', juz 5, Beirut: al-Kitab al-'Alami Li al-Nasyri, 2005.

Muhammad Jawwad Mughniyah. Fiqh Lima Madz̧ab, Jakarta: Lentera Basritama, 1996.

Sayyid Sabiq. Fikih Sunnah Jilid 14, cet.2, Bandung: Al Ma'arif, 1988.

Sudarsono. Hukum Waris dan Sistem Bilateral, Jakarta: PT. Melton Putra, 1991.

Suhardana, et al. Hukum Perdata 1 Buku Panduan Mahasiswa. Jakarta: PT. Gramedia Pustaka Utama, 1996.

Suhrawardi K. Lubis. Hukum Waris Islam (Lengkap \& Praktis), Jakarta: Sinar Grafika, 1995.

Sulaiman Rasjid. Fiqh Islam, Bandung: Sinar Baru Algensindo, 2008.

ST. M. Hasby Ash Shiddieqiy. Fiqh Mawaris, Semarang: Pustaka Rizki Putra, 1997.

Wahbah Zuhaily. Al-Figh al-Islam wa Adillatubu, juz 8, Damaskus: Dar al-Fikr, 2008.

Zainuddin Ali. Hukum Perdata Islam di Indonesia, Jakarta: Sinar Grafika, 2009. 